\title{
Simultaneous Determination of Binary Drug Components in Pharmaceutical Formulations with Chemometric Methods
}

\section{Güzide PEKCAN ERTOKUŞ ${ }^{* 1}$, Mine BİNECİ DOĞAN ${ }^{1}$}

\begin{abstract}
A synchronous definition of paracetamol and amoxicillin quantities in pharmaceutical formulations was performed using spectrophotometric methods. Principal component regression (PCR) and partial least squares regression (PLS) were used as multivariate calibration techniques. Spectrophotometric-chemometric methods were used for the simultaneous quantification of paracetamol and amoxicillin in the laboratory prepared mixtures and in the drug tablets without any requirements for a prior separation. The linearity of the calibration curves for each active substance in the synthetic mixtures demonstrated that concentration ranges were appropriate $\left(r^{2}>0.9997\right)$. The investigation of the accuracy and repeatability of the two methods resulted in high recovery rates and lower standard deviation values. Achieving high recovery and low standard deviation values, this study encouraged us to proceed further in pharmaceutical assay. The recommended methods are highly sensitive and precise as these methods have been successfully applied to quantify active substances in pharmaceutical samples.
\end{abstract}

Keywords: Paracetamol, Amoxicillin, PLS, PCR.

\section{Farmasötik Formülasyonlardaki İkili İlaç Bileşenlerinin Eş Zamanlı Olarak Kemometrik Metotlarla Tayini}

ÖZET: Farmasötik formülasyonlardaki parasetamol ve amoksisilin miktarlarının spektrofotometrik olarak eş zamanlı tayini yapılmıştır. Çok değişkenli kalibrasyon tekniklerinden temel bileşen regresyonu (TBR) ve kısmi en küçük kareler yöntemi (KEKK) kullanılmıştır. Spektrofotometrik-kemometrik metotlar kullanılarak, hem laboratuvarda hazırlanan sentetik karışımların hem de ilaç tabletlerinin hiçbir ön ayırma yapılmadan analizi sağlanmıştır. Sentetik karışımlardaki her aktif madde için kalibrasyon eğrilerinin doğrusallığı, konsantrasyon aralıklarının uygun olduğu gözlenmiştir ( $\left.{ }^{2}>0,9997\right)$. İki yöntemin doğruluğu ve tekrarlanabilirliği incelendiğinde yüksek geri kazanım ve düşük standart sapma değerleri elde edilmiştir. Yüksek geri kazanım ve düşük standart sapma değerleri, bu çalışmada ilaç tablet analizleri konusunda bizi cesaretlendirmiştir. Önerilen metotlar, farmasötik örneklerdeki aktif bileşenlerin tayininin başarıyla uygulanması yönünden oldukça yüksek kesinlik ve duyarlılığa sahiptir.

Anahtar Kelimeler: Parasetamol, Amoksisilin, PLS, PCR.

${ }^{1}$ Güzide Pekcan Ertokuş (Orcid ID: 0000-0001-9230-5634), Mine Bineci Doğan (Orcid ID: 0000-0001-8484-913X), Süleyman Demirel Üniversitesi, Fen-Edebiyat Fakültesi, Kimya Bölümü, Isparta, Türkiye

*Sorumlu Yazar/Corresponding Author: Güzide Pekcan Ertokuş, e-mail: guzideertokus@sdu.edu.tr

* Bu çalışma Mine Bineci Doğan'ın Yüksek Lisans tezinden üretilmiştir.

Geliş tarihi / Received: 24-12-2019

Kabul tarihi / Accepted: 09-02-2020 


\section{INTRODUCTION}

Amoxicillin, a semi-synthetic $\beta$-lactam in the penicillin group, is a type of antibiotic is in the treatment for gastrointestinal system infections with Helicobacter pylori (Horoz et al., 2004; Rojanarata et al., 2010; Aktaş et al., 2017). Amoxicillin is chemically $\mathrm{C}_{16} \mathrm{H}_{19} \mathrm{~N}_{3} \mathrm{O}_{5} \mathrm{~S}$ (Reiss et al., 2015). Paracetamol, $\mathrm{C}_{8} \mathrm{H}_{9} \mathrm{NO}_{2}$, is widely used as an analgesic and antipyretic drug worldwide (Mohamed et al., 2017; Shanker et al., 2017). Paracetamol is commercially available in several medications in combination with other pharmaceuticals at different rates (Cunha et al., 2017). Paracetamol is quantified by UV spectroscopy (Dinç, 2003; Hajian et al., 2012; Behera et al., 2012; Hajian and Soltaninezhad, 2013; Aktaş and Kitiş, 2014; Saraan et al., 2015; Zahira et al., 2015; Wedian, 2016; Glavanovic et al., 2016) and HPLC (Attimarad, 2011; Talluri et al., 2012; Sharma et al., 2016). Amoxicillin is determined with HPLC (Aktaş et al., 2017) and UV spectroscopy (Ertokuş and Bağrıaçık, 2017), too.

Spectrophotometric methods are widely used for the simultaneous quantification of distinct molecules in combinations. The results are reported to be accurate, precise and it is stated that the method is inexpensive (Mansour, 2018). Partial least squares regression (PLS) and principal component regression (PCR) are the most frequently used chemometric methods (Dinç and Baleanu, 2002). The analysis of multicomponent pharmaceutical products using these methods are well-accepted (Kenneth, 1997).

The mathematical science (Aktaş and Ünlü, 2016) supported chemometry allows analytical analysis of two or more substances, even in overlapping spectra (Aktaş and Toprak, 2017). The Minitab 17 program (Inova, Ankara, Turkey) (İnova Danışmanlık, 2019) is a statistical analysis software used not only for performing statistical analyses but for training in statistics as well. It allows statistical analysis by using the relationship between Minitab and absorbance-concentration.

In this study; the quantification of paracetamol and amoxicillin in pharmaceutical combinations (Parol and Alfoxil) were performed by PLS and PCR. Amoxicillin and paracetamol are usually given to patients to be taken simultaneously for a combination of their antibiotic and analgesic effects. Starting from this point, using the available medications of these two molecules, we prepared a drug sample containing a combination of amoxicillin and paracetamol. The validation of the chemometricspectrophotometric method used in this study is included as an appendix to this article presenting the precision, accuracy, and selectivity of the methods. PLS and PCR methods successfully identified and quantified paracetamol and amoxicillin present in the drug combination simultaneously without any prior separation. Mean recoveries (\%), the standard deviation of principal component regression (PCR), and partial least squares regression (PLS) methods were used for the validation of the methods used in the study. The data were statistically crosschecked with their respective counterparts.

\section{MATERIAL AND METHODS}

Stock solutions were prepared at $25 \mathrm{mg}$ in $250 \mathrm{ml}$ concentration using Paracetamol (Sigma) and amoxicillin (Sigma) $\mathrm{HCl}$ in analytical purity. A concentration set was prepared to contain these two drugs in various proportions. Consequently, 25 distinct synthetic mixtures were prepared to be used for validation and calibration and the absorption measurement of the substance was done with s Shimadzu UV-1700 PharmaSpec Spectrophotometer.

Absorption values of drug active compounds were saved at 200 to $350 \mathrm{~nm}$. The training and validation sets containing two component in different proportions were used for calculating the concentrations and the concentration sets. The analysis of the drug mixtures was performed using chemometric methods. Mixtures of 5.0-25.0 mg L-1 of active substance were put in volumetric flasks $(25 \mathrm{ml}$ ) and dissolved in $0.1 \mathrm{M} \mathrm{HCl}$. A training set, a validation set, and 25 synthetic mixtures (for 
validation and calibration) containing the drugs in various proportions were prepared. They are presented in Table 1.

Table 1. Concentration set for paracetamol and amoxicillin (Ertokuş, 2018).

\begin{tabular}{|c|c|c|c|c|c|}
\hline \multirow{2}{*}{ No. } & \multicolumn{5}{|c|}{ Concentration, $\mathrm{mg} \mathrm{L}^{-1}$} \\
\hline & Paracetamol & Amoxicillin & No. & Paracetamol & Amoxicillin \\
\hline 1 & 5 & 5 & 13 & 15 & 15 \\
\hline 2 & 5 & 10 & 14 & 15 & 20 \\
\hline 3 & 5 & 15 & 15 & 15 & 25 \\
\hline 4 & 5 & 20 & 16 & 20 & 5 \\
\hline 5 & 5 & 25 & 17 & 20 & 10 \\
\hline 6 & 10 & 5 & 18 & 20 & 15 \\
\hline 7 & 10 & 10 & 19 & 20 & 20 \\
\hline 8 & 10 & 15 & 20 & 20 & 25 \\
\hline 9 & 10 & 20 & 21 & 25 & 5 \\
\hline 10 & 10 & 25 & 22 & 25 & 10 \\
\hline 11 & 15 & 5 & 23 & 25 & 15 \\
\hline \multirow[t]{2}{*}{12} & 15 & 10 & 24 & 25 & 20 \\
\hline & & & 25 & 25 & 25 \\
\hline
\end{tabular}

\section{Preparation of Pharmaceutical Preparations}

A commercial dosage form Parol tablets produced by Atabay, containing $500 \mathrm{mg}$ of paracetamol per tablet and Alfoxil tablets produced by Actavis, containing $500 \mathrm{mg}$ of amoxicillin per tablet were analyzed by multivarite calibration methods. While preparing the drug sample to be examined, both the parol and all of the alfoxil drugs were mixed. The mixture was crushed and mixed in agate air to provide homogeneity. Paracetamol and amoxicillin were determined from the prepared mixture. For this purpose, weighing one tablet was dissolved in $0.1 \mathrm{M} \mathrm{HCl}$ and then the final volume is completed to 25 $\mathrm{mL}$.

\section{RESULTS AND DISCUSSION}

Absorption of paracetamol and amoxicillin and of the mixed solution were all in the visible range of highly absorbent substances (Figure 1.).

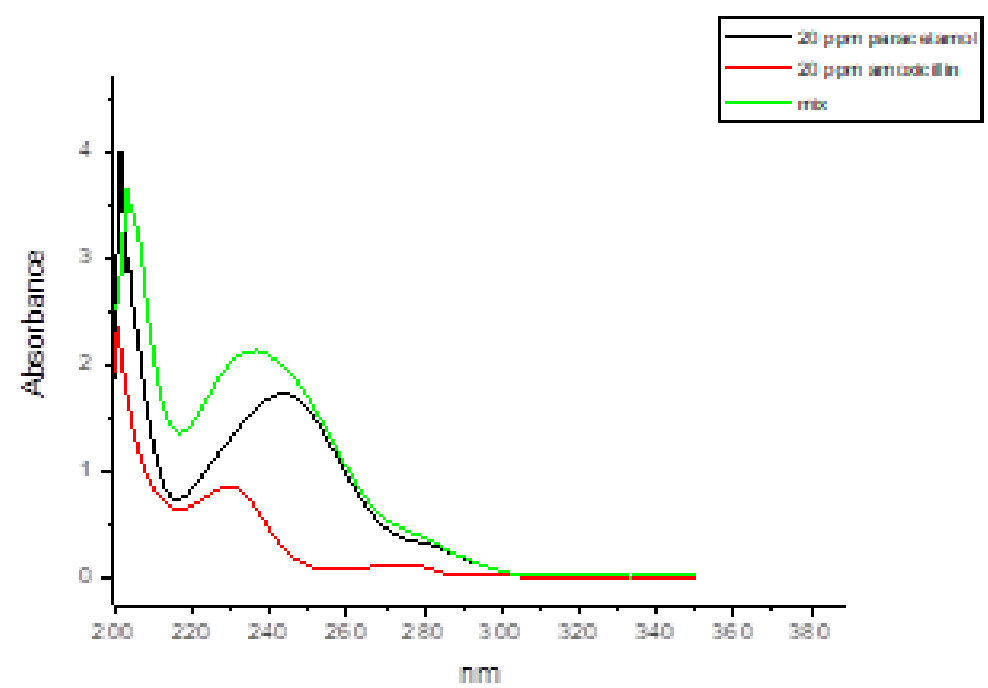

Figure 1. Absorption spectra of $20 \mathrm{mg} \mathrm{L}^{-1}$ paracetamol, $20 \mathrm{mg} \mathrm{L}^{-1}$ amoxicillin and and their mixture.

When the absorbance-concentration relationship of paracetamol and amoxicillin is examined, it is observed that the absorbance value increases with increasing concentration. The linear relationship 
(Miao et al., 2018) between absorbance and concentration values is evaluated by the high value of the regression coefficient (Uyanık, 2012) (Table 4.).

The concentration values in the range of 5.0-25.00 ppm used in the study are the area where the linearity for each component was to be determined. According to Lambert-Beer (Uyanik, 2012), when the relationship between absorbance and concentration is examined, it is observed that the linear correlation coefficient (Sharma et al., 2017) between the two variables is close to each other (Table 4.).

\section{Chemometric Methods}

Some statistical parameters were introduced for the validation of calibrations for synthetic mixtures of drugs. Recovery and relative standard deviation (rsd) values calculated for each chemometric method 1 are shown in Table 2, Table 3,. While the concentrations against the added concentrations were calculated, the cross-validation procedure was applied to prevent errors in the drug sample (Porfire et al., 2015; Tarhan and Kara, 2017).

\section{Method Validation}

The chemometric method was validated in accordance with ICH guidelines (Abbai and Parameswari, 2009; Aravind and Kamarapu, 2013; Despande and Mandawad, 2018;) with respect to linearity, accuracy, intraday and interday precision, limit of detection, and limit of quantitation. For calibration, According to the actual and predicted concentrations of the samples, the prediction of the residual error sum-of-squares (PRESS) and standard error of prediction (SEC) (Table 4.) was calculated with the formula below:

$$
\text { PRESS }=\sum_{i=1}^{n}\left(C_{i}^{\text {added }}-C_{i}^{\text {found }}\right)^{2}
$$

where $C_{i}^{\text {added }}$ - actual concentration, the added concentration of the drug; $C_{i}^{\text {found }}$ : predicted concentration, the calculated concentration of the drug.

$$
S E C=\sqrt{\frac{\sum_{i=1}^{n}\left(C_{i}^{\text {added }}-C_{i}^{\text {found }}\right)^{2}}{n-1}}
$$

where $n-$ the total number of synthetic mixtures.

Another validation parameter is RMSEC (Bilgili et al., 2014). It is given in the below equation 3 .

$$
\mathrm{RMSEC}=\sqrt{P R E S S / n}
$$

The equations of the observable limit (LOD) and detection limit (LOQ) parameters are shown below. These expressions are interrelated but have different equations (equation 4 and 5) (Shrivastava and Gupta, 2011).

$$
\begin{aligned}
& \mathrm{LOD}=3 \mathrm{Sa} / \mathrm{m} \\
& \mathrm{LOQ}=10 \mathrm{Sa} / \mathrm{m}
\end{aligned}
$$

m: Slope 
LOQ > LOD and LOQ = LOD were taken into consideration while evaluating the calculated LOD values (Armbruster and Pty, 2008).

Table 2. Recovery results for PLS method

\begin{tabular}{|c|c|c|c|c|c|c|}
\hline \multirow[b]{2}{*}{ No } & \multicolumn{3}{|c|}{ Paracetamol } & \multicolumn{3}{|c|}{ Amoxicillin } \\
\hline & $\begin{array}{c}\text { Added } \\
(\mathrm{ppm})\end{array}$ & $\begin{array}{l}\text { Found } \\
\text { (ppm) }\end{array}$ & Recovery \% & $\begin{array}{c}\text { Added } \\
(\mathrm{ppm})\end{array}$ & $\begin{array}{l}\text { Found } \\
\text { (ppm) }\end{array}$ & Recovery \% \\
\hline 1 & 5 & 4.99 & 99.80 & 5 & 5.00 & 100.00 \\
\hline 2 & 5 & 4.87 & 97.40 & 10 & 9.98 & 99.8 \\
\hline 3 & 5 & 4.85 & 97.00 & 15 & 14.96 & 99.73 \\
\hline 4 & 5 & 4.88 & 97.60 & 20 & 19.97 & 99.85 \\
\hline 5 & 5 & 4.92 & 98.40 & 25 & 24.97 & 99.88 \\
\hline 6 & 10 & 9.96 & 99.60 & 5 & 4.96 & 99.20 \\
\hline 7 & 10 & 9.87 & 98.70 & 10 & 9.92 & 99.20 \\
\hline 8 & 10 & 9.84 & 98.40 & 15 & 14.97 & 99.80 \\
\hline 9 & 10 & 9.95 & 99.50 & 20 & 18.89 & 94.45 \\
\hline 10 & 10 & 9.92 & 99.20 & 25 & 24.95 & 99.80 \\
\hline 11 & 15 & 14.96 & 99.73 & 5 & 5.01 & 100.20 \\
\hline 12 & 15 & 14.97 & 99.80 & 10 & 9.96 & 99.60 \\
\hline 13 & 15 & 14.89 & 99.27 & 15 & 14.92 & 99.47 \\
\hline 14 & 15 & 14.94 & 99.60 & 20 & 19.92 & 99.60 \\
\hline 15 & 15 & 14.95 & 99.67 & 25 & 24.89 & 99.56 \\
\hline 16 & 20 & 19.98 & 99.90 & 5 & 4.97 & 99.40 \\
\hline 17 & 20 & 19.95 & 99.75 & 10 & 9.99 & 99.90 \\
\hline 18 & 20 & 19.89 & 99.45 & 15 & 14.97 & 99.80 \\
\hline 19 & 20 & 19.97 & 99.85 & 20 & 19.96 & 99.80 \\
\hline 20 & 20 & 19.97 & 99.85 & 25 & 24.96 & 99.84 \\
\hline 21 & 25 & 24.96 & 99.84 & 5 & 4.96 & 99.20 \\
\hline 22 & 25 & 24.98 & 99.92 & 10 & 9.97 & 99.70 \\
\hline 23 & 25 & 24.97 & 99.88 & 15 & 14.93 & 99.53 \\
\hline 24 & 25 & 25.01 & 100.04 & 20 & 19.87 & 100.04 \\
\hline \multirow[t]{2}{*}{25} & 25 & 25.01 & 100.04 & 25 & 24.97 & 100.04 \\
\hline & & & $\begin{array}{l}\text { Mean }=99.29 \\
\% \mathrm{RSD}=0.87\end{array}$ & & & $\begin{array}{c}\text { Mean }=99.50 \\
\% \mathrm{RSD}=1.08\end{array}$ \\
\hline
\end{tabular}

Table 3. Recovery results for PCR method

\begin{tabular}{ccccccc}
\hline No & \multicolumn{3}{c}{ Paracetamol } & \multicolumn{3}{c}{ Amoxicillin } \\
\cline { 2 - 7 }$(\mathbf{p p m})$ & $\begin{array}{c}\text { Found } \\
(\mathbf{p p m})\end{array}$ & Recovery \% & $\begin{array}{c}\text { Added } \\
(\mathbf{p p m})\end{array}$ & $\begin{array}{c}\text { Found } \\
(\mathbf{p p m})\end{array}$ & Recovery \% \\
\hline 1 & 5 & 5 & 100.00 & 5 & 4.98 & 99.60 \\
2 & 5 & 4.98 & 99.60 & 10 & 9.89 & 98.90 \\
3 & 5 & 4.97 & 99.40 & 15 & 14.87 & 99.13 \\
4 & 5 & 4.89 & 97.80 & 20 & 19.99 & 99.95 \\
5 & 5 & 4.9 & 98.00 & 25 & 24.92 & 99.68 \\
6 & 10 & 9.95 & 99.50 & 5 & 4.89 & 97.80 \\
7 & 10 & 9.92 & 99.20 & 10 & 9.95 & 99.50 \\
8 & 10 & 9.94 & 99.40 & 15 & 14.99 & 99.93 \\
9 & 10 & 9.97 & 99.70 & 20 & 19.96 & 99.80 \\
10 & 10 & 10.01 & 100.10 & 25 & 24.89 & 99.56 \\
11 & 15 & 14.97 & 99.80 & 5 & 4.92 & 98.40 \\
12 & 15 & 14.96 & 99.73 & 10 & 9.87 & 98.70 \\
13 & 15 & 14.92 & 99.47 & 15 & 14.92 & 99.47 \\
14 & 15 & 15.01 & 100.07 & 20 & 19.87 & 99.35 \\
15 & 15 & 14.89 & 99.27 & 25 & 24.9 & 99.60 \\
16 & 20 & 19.97 & 99.85 & 5 & 4.91 & 98.20 \\
\hline
\end{tabular}


Table 3. Recovery results for PCR method (contitnued)

\begin{tabular}{ccccccc}
\hline \multirow{2}{*}{ No } & \multicolumn{3}{c}{ Paracetamol } & \multicolumn{2}{c}{ Amoxicillin } \\
\cline { 2 - 7 } & $\begin{array}{c}\text { Added } \\
(\mathbf{p p m})\end{array}$ & $\begin{array}{c}\text { Found } \\
(\mathbf{p p m})\end{array}$ & Recovery \% & $\begin{array}{c}\text { Added } \\
(\mathbf{p p m})\end{array}$ & $\begin{array}{c}\text { Found } \\
(\mathbf{p p m})\end{array}$ & Recovery \% \\
\hline 17 & 20 & 19.99 & 99.95 & 10 & 9.88 & 98.80 \\
18 & 20 & 19.97 & 99.85 & 15 & 14.94 & 99.60 \\
19 & 20 & 19.96 & 99.80 & 20 & 19.95 & 99.75 \\
20 & 20 & 19.94 & 99.70 & 25 & 24.94 & 99.76 \\
21 & 25 & 24.96 & 99.84 & 5 & 4.86 & 97.20 \\
22 & 25 & 24.97 & 99.88 & 10 & 9.88 & 98.80 \\
23 & 25 & 24.93 & 99.72 & 15 & 14.92 & 99.47 \\
24 & 25 & 24.98 & 100.04 & 20 & 19.88 & 100.04 \\
25 & 25 & 24.97 & 100.04 & 25 & 24.85 & 100.04 \\
\hline & \multicolumn{7}{c}{ Mean=99.59 } & & Mean $=99.24$ \\
\end{tabular}

Table 4. Calculated Analytical Parameters

\begin{tabular}{lccc}
\hline Parameters & Method & Paracetamol & Amoxicillin \\
\hline$\chi_{\max }(\mathbf{n m})$ & & $243.50 \mathrm{~nm}$ & $229.50 \mathrm{~nm}$ \\
Regression Equation*(y) & Y=a+bx & Y=0.064x-0.011 & Y=0.022x-0.009 \\
Slope (b) & & 0.064 & 0.022 \\
Intercept (a) & & 0.011 & 0.009 \\
Correlation Coefficient $\left(\mathbf{R}^{2}\right)$ & PLS & 0.9997 & 0.9992 \\
SEC & PCR & 0.021 & 0.031 \\
& PLS & 0.017 & 0.029 \\
PRESS & PCR & 0.0063 & 0.055 \\
& PLS & 0.004 & 0.009 \\
RMSEC & PCR & 0.016 & 0.047 \\
& PLS & 0.013 & 0.019 \\
LOD $(\boldsymbol{\mu g} / \mathbf{m L})$ & PCR & 0.060 & 0.334 \\
LOQ $(\boldsymbol{\mu g} / \mathbf{m L})$ & PLS & 0.053 & 0.064 \\
& PCR & 0.183 & 1.010 \\
Accuracy (\% Recovery \pm SD) & PLS & 0.159 & 0.195 \\
Precision (Reproducibility) & PCR & $99.29 \pm 0.87$ & $99.50 \pm 1.08$ \\
Intraday (\% Recovery \pm SD) $(\mathbf{n : 6 )}$ & & $99.59 \pm 0.57$ & $99.24 \pm 0.73$ \\
Interday (\% Recovery \pm SD) $(\mathbf{n : 6 )}$ & PLS & $99.57 \pm 0.92$ & $99.95 \pm 0.54$ \\
\hline
\end{tabular}

${ }^{*} \mathrm{y}=\mathrm{a}+\mathrm{bx}$, where $\mathrm{y}$ is the absorbance and $\mathrm{x}$ is the concentration of paracetamol and amoxicillin.

PRESS and SEP values were close to zero with the PLS and PCR methods. The degree of accuracy showed an increasing pattern.

\section{Analysis of the Pharmaceutical Formulations}

The calculated values of chemometric methods for the pharmaceutical formulations are shown in Table 5. The results obtained are very close to each other.

Snedecor's $F$-test (Bajpai et al., 2017) and student's t-test were applied to chemometric results. For student's t-test, $\mathrm{p}>0.05$ was found and the variances were homogeneous; i.e., the results obtained with PLS and PCR methods were compatible. For Paracetamol, the p-value was 0.194 and for amoxicillin, the p-value was 0.450. Considering all these methods, it was concluded that there was a meaningful difference. All statistical parameters and numeric values were appropriate for simultaneous identification in pharmaceutical formulations. 
Table 5. The amount of paracetamol and amoxicillin in the pharmaceutical formulation harvested using PLS and PCR methods.

\begin{tabular}{|c|c|c|c|}
\hline \multirow[b]{2}{*}{ NO } & \multicolumn{3}{|c|}{ Paracetamol (gram) } \\
\hline & PLS & PCR & Classical UV \\
\hline 1 & 0.480 & 0.495 & 0.492 \\
\hline 2 & 0.495 & 0.497 & 0.496 \\
\hline 3 & 0.492 & 0.498 & 0.495 \\
\hline 4 & 0.497 & 0.497 & 0.495 \\
\hline 5 & 0.499 & 0.496 & 0.495 \\
\hline Mean \pm SD* & $0.4926 \pm 0.0075$ & $0.4966 \pm 0.0011$ & $0.4946 \pm 0.0015$ \\
\hline NO & $\begin{array}{l}\text { Amoxicillion(gram) } \\
\text { PLS }\end{array}$ & PCR & Classical UV \\
\hline 1 & 0.485 & 0.498 & 0.496 \\
\hline 2 & 0.496 & 0.497 & 0.494 \\
\hline 3 & 0.495 & 0.489 & 0.497 \\
\hline 4 & 0.497 & 0.488 & 0.499 \\
\hline 5 & 0.496 & 0.496 & 0.498 \\
\hline Mean \pm SD* & $0.4938 \pm 0.0050$ & $0.4936 \pm 0.0047$ & $0.4968 \pm 0.0019$ \\
\hline
\end{tabular}

*SD: Standard Deviation

\section{CONCLUSION}

The proposed multivariate calibration methods are fast, precise and correct for the simultaneous determination of pharmaceutical formulations containing paracetamol and amoxicillin drugs having overlapping spectra. In this study, PLS and PCR methods were applied to the simultaneous quantitative prediction of paracetamol and amoxicillin in pharmaceutical formulations without requiring any separation step. For all values, low prediction errors and high correlation coefficients emphasized the high linear relationship between the predicted and actual concentrations. The results obtained from the binary mixtures and the results associated with the concentration ratios of some components showed excellent predictive ability with these methods.

\section{REFERENCES}

Abbai N, Parameswari SA, 2009. Stability Indicating RP-HPLC Method Development and Validation for Simultaneous Estimation od Salbutamol and Beclomethasone in Bulk and Tablet Dosage Form. IJPSR 9(5): 1980-1988.

Aktaş AH, Sarıdağ AM, 2017. Liquid Chromatographic-Chemometric Techniques For The Simultaneous HPLC Determination of Lansoprazole, Amoxicillin and Clarithromycin in Commercial Preparation. Journal of Chromatographic Science 1-7.

Aktaş AH, Kitiş F, 2014. Spectrophotometric Simultaneous Determination Of Caffeine And Paracetamol In Commercial Pharmaceutical By Principal Component Regression, Partial Least Squares And Artificial Neural Networks Chemometric Methods. Croatica Chemica Acta 87(1): 69-74.

Aktaş AH, Toprak HH, 2017. Spectrometric Determination of Lansoprazole and Domperidone in Tablets by Multivariate Calibration Approach. Journal of Chemical and Pharmaceutical Research 9(3): 103-108.

Aktaş AH, Ünlü İD, 2016. Application of PCA-ANN Models to Spectrophotometric Data For Quantitative Analysis of A Hydrochlorothiazide and Amiloride Hydrochlorothiazide in Pharmaceutical Formulations. Journal of Chemical and Pharmaceutical Research 8(2): 743-749.

Aravind D, Kamarapu SK, 2013. Method Development and Validation of RP-HPLC Method for Simultaneous Estimation of Clidinium Bromide, Chlordiazepoxide and Dicylomine Hydrochloride in Bulk and Combined Tablet Dosage Forms. IJPBS 3(3): 152-161.

Armbruster DA, Pty T, 2008. Limit of Blank, Limit of Detection and Limit of Quantitation. Clin. Niochem Rev. 29: 49-52. 
Attimarad M, 2011. Simultaneous Determination of Paracetamol and Lornoxicam by RP-HPLC in Bulk and Tablet Formulation. Pharmaceutical Methods 2(1): 61-66.

Bajpai V, Kumar S, Singh A, Singh J, Negi MPS, Bag SK, Kumar N, Konwar R, Kumar B, 2017. Chemometric Based Identification and Validation of Specific Chemical Markers for Goegraphical, Seasonal and Gender Variations in Tinospora Cordifolia Stem Using HPLC-ESI-QTOF-MS Analysis. Photochemical Analysis 28(4): 277-288.

Behera S, Ghanty S, Ahmad F, Santra S, Banerjee S, 2012. UV-Visible Spectrophotometric Method Development and Validation of Assay of Paracetamol Tablet Formulation. Journal of Analytical and Bioanalytical Techniques 3-6.

Bilgili AV, Çullu MA, Aydemir S, 2014. Tuzdan Etkilenmiş Toprakların Yakın Kızılötesi Yansıma Spektroradyometre ve Elektromanyetik Indüksiyon Tekniği Yardımılla Karakterize Edilebilme Potansiyelinin Araştırılması. Harran Tarım ve Gıda Bilimleri Dergisi 18(1): 32-45.

Cunha RR, Ribeiro MMAC, Munoz RAA, Richter EM, 2017. Fast Determination of Codeine, Orphenadrine, Promethazine, Scopolamine, Tramadol and Paracetamol in Pharmaceutical Formulations by Capillary Electrophoresis. Journal of Separation Science 40: 1815-1823.

Deshpande P, Mandawad V, 2018. Development and Validation of Stability Indicating HPTLC Method for Determination of Azelastine Hydrochloride as Bulk Drug and in Pharmaceutical Liquid Dosage Form. IAJPS 05(06): 5107-5113.

Dinç E, 2003. Linear Regression Analysis and Its Application to The Multivariate Spectral Calibrations For The Multiresolution of A Ternary Mixture of Caffeine, Paracetamol and Metamizol in Tablets. Journal of Pharmaceutical and Biomedical Analysis 33: 605-615.

Dinç E, Baleanu D, 2002. Spectrophotometric Quantitative Determination of Cilazapril and Hydrochlorothiazide in Tablets By Chemometric Methods. J. Pharmaceut. Biomed 30: 715-723.

Ertokuş Pekcan, G, 2018. Determination of Binary Drug Compounds by Spectrophotometric Methods and Determination of The Data Obtained as A Statistical. European Conference on Science, Art \& Culture (ECSAC) 43-49.

Ertokuş GP, Bağraç̧ı K, 2017. Simultaneous Determination of Drugs Used For Chronic Active Gastritis Disease by Chemometric Methods. IJLTET 8(4): 173-178.

Glavanovic S, Glavanovic M, Tomisic V, 2016. Simultaneous Quantitative Determination of Paracetamol and Tramadol in Tablet Formulation Using UV Spectrophotometry and Chemometric Methods. Spectrochimica Acta Part A:Molecular and Biomolecular Spectroscopy 157: 258-264.

Hajian R, Afshari N, 2012. The Spectrophotometric Multicomponent Analysis of A Ternary Mixture of Ibuprofen, Caffeine and Paracetamol by The Combination of Double Divisor-Ratio Spectra Derivative and H-point Standard Addition Method. E-journal of Chemistry 9(3): 1153-1164.

Hajian R, Soltaninezhad A, 2013. The Spectrophotometric Multicomponent Analysis of A Ternary Mixture of Paracetamol, Aspirin and Caffeine by The Double Divisor-ratio Spectra Derivative method. Journal of Spectroscopy 1-7.

Horoz M, Bölükbaş C, Bölükbaş FF, Uzunköy A, Soylu A, 2004. Klaritromisin-Amoksisilin-Lansoprazol Kombinasyonunda Optimal Tedavi Süresi. HrÜ. Tıp Fak. Der. 1: 12-19.

Kenneth R, 1997. Chemometrics: A practical Guide. John Wiley \& Sons. Inc., New York.

Mansour FR, 2018. A New Innovative Spectrophotometric Method For The Simultaneous Determination of Sofosbuvir and Ledipasvir. Spectrochimica Acta Part A:Molecular and Biomolecular Spectroscopy 18(188): 626-632.

Miao J, Forget B, Smith K, 2018. Predicting Correlation Coefficients for Monte Carlo Eigenvalue Simulations With Multitype Branching Process Annals of Nuclear Energy 112: 307-321.

Minitab 18 Statistical Programme. http://www.inovadanismanlik.com.tr/_tu/_urunler/_minitab18/m18.html (13.10.2019) 
Mohamed EH, Lofty HM, Hegazy MA, Mowaka S, 2017. Different Applications of Isosbestic Points, Normalized Spectra and Dual Wavelength as Powerful Tools for Resolution of Multicomponent Mixtures with Severely Overlapping Spectra. Chemistry Central Journal 11(43): 1-15.

Porfire A, Muntean D, Achim M, Vlase L, Tomuta, I, 2015. Simultaneous Quantification of Simvastatin and Excipients in Liposomes Using Near Infrared Spectroscopy and Chemometry. Journal of Pharmaceutical and Biomedical Analysis 107: 40-49.

Reiss A, Samide A, Ciobanu G, Dabuleanu I, 2015, Synthesis, Spectral Characterization and Thermal Behaviour of New Metal (II) Complexes with Schiff Base Derived From Amoxicillin. J.Chil. Chem. Soc. 3: 30743079 .

Rojanarata T, Opanasopit P, Ngawhirunpat T, Saehuan C, Wiyakrutta S, Meevootisom V, 2010. A Simple, Sensitive and Green Bienzymatic UV-Spectrophotometric Assay of Amoxicillin Formulations. Enzyme and Microbial Technology 46: 292-296.

Saraan SMD, Sinaga SM, Muchlisyam 2015. Development Method For The Determination of Ternary Mixture of Paracetamol, Ibuprofen and Caffeine in Tablet Dosage Form Using Zero-Crossing Derivative Spectrophotometric. International Journal of Pharmtach Research 7(2): 349-353.

Shanker K, Kuna SK, Purra S, 2017. Simultaneous Determination of Etodolac and Paracetamol in Bulk Drugs and Pharmaceutical Formulation by HPTLC-Densitometric and UV-derivative Spectrophotometry Methods. IJPSR 8(5): 2056-2063.

Sharma D, Singh R, Garg R, 2017. Development and Validation of Stability Indicating UV Spectro-photometric Method For The Estimation of Benzydamine Hydrochloride in Bulk and in Pharmaceutical Dosage Form: A Novel Analytical Technique For Conducting In-Vitro Quality Control Tests. International Journal Of Pharmaceutical Sciences And Research 9(2): 678-686.

Sharma H, Vishakha K, Kumar KV, Bhatta HP, 2016. Validated RP-HPLC Method for Simultaneous Estimation of Paracetamol, Pamabrom and Dicyclomine, Hydrochloride in Bulk and Pharmaceutical Dosage Form. IJPRS 7(1): 316-324.

Shrivastava A, Gupta VB, 2011. Methods For The Determination of Limit of Detection and Limit of Quantitation of The Analytical Methods. Chronicles of Young Scientist 2(1): 21-25.

Talluri MVNK, Bairwa MK, Dugga HHT, Srinivas R, 2012. Development and Validation of RP-HPLC and Ultraviolet Spectrophotometric Methods of Analysis for Simultaneous Determination of Paracetamol and Lornoxicam in Pharmaceutical Dosage Forms. Journal of Liquid Chromatography \& Related Technologies 35: $129-140$.

Tarhan I, Kara AAIH, 2017. Quantitative Determination of Free Fatty Acids in Extra Virgin Olive Oils by Multivariate Methods and Fourier Transform Infrared Spectroscopy Considering Different Absorption Modes. International Journal of Food Properties 1-8.

Uyanık A, 2012. Analitik Kimyacılar İçin İstatistik ve Kemometri, Pegem Akademi Yayıncılık 6. Baskı:254259.

Wedian F, 2016. Bivariate Analysis For The Determination of Paracetamol and Caffeine in Drug Formulation. Jordan Journal of Chemistry 11(4): 217-225.

Zahira NK, Prasannakumaran PN, 2015. Analytical Method Development and Validation of Zaltoprofen and Paracetamol in Combined Dosage Form by Ultraviolet Spectrophotometry. IJPSR 6(2): 682-687. 